\title{
Badanie komunikacji partii politycznych na podstawie fotografii publikowanych w Internecie
}

\section{Wstęp}

Internet pozwala partiom politycznym na publikowanie w dowolnym czasie różnych materiałów własnego autorstwa, bez konieczności ponoszenia znaczących kosztów. Wśród nich występują między innymi fotografie, na których widoczne są różne osoby, wydarzenia i miejsca. Do umieszczenia w Internecie zostały wybrane te, a nie inne zdjęcia, zatem to, co jest widoczne na partyjnych profilach i stronach, z jakiegoś powodu zostało uznane za warte publikacji. Zbadanie tych materiałów pod kątem pewnych schematów i prawidłowości może dostarczyć interesujących informacji na temat partii politycznych, ich struktur oraz działań. Podczas analizy pojedynczych fotografii pewne szczegóły mogą pozostać niezauważone bądź wydać się mało istotne, dlatego potrzeba całościowego spojrzenia, które zapewnić może badanie o charakterze ilościowym. Zbadane zostały zbiory fotografii opublikowanych w Internecie przez dwie polskie partie polityczne. Sprawdzone zostało między innymi to, jakie typy fotografii pojawiają się najczęściej, jakie wydarzenia są pokazywane na zdjęciach, jakie osoby (i w jaki sposób) są prezentowane oraz jakie obiekty i symbole są widoczne.

\section{Metoda badawcza i cele badania}

Analizie poddane zostały materiały wizualne opublikowane na portalu Facebook przez partię Razem oraz partię Wolność (funkcjonującą wcześniej pod nazwą KOR- 
WiN $)^{1}$. Ugrupowania te zostały wybrane, ponieważ w wyborach parlamentarnych w 2015 roku uzyskały najwyższe wyniki spośród tych partii, które nie przekroczyły $5 \%$ progu wyborczego ${ }^{2}$. Mimo zbliżonych wyników, ich stanowiska polityczne zdają się być zupełnie odmienne. W deklaracji programowej partii Razem można przeczytać, że:

Razem to Polska, która wygląda inaczej. Prawo może stać po stronie pracowników. Państwo może zapewniać tanie mieszkania czynszowe, bezpłatne żłobki i solidną opiekę lekarską. Da się zagwarantować stabilne warunki pracy i godne płace ${ }^{3}$.

Natomiast fragment deklaracji ideowej partii Wolność wygląda następująco:

Łączy nas przekonanie, że władze, a w szczególności władza ustawodawcza, winny powstrzymywać się przed ingerencją w obszar wolności człowieka wyznaczony przez prawa naturalne, chyba że jest to niezbędne dla ochrony życia, wolności lub własności innych osób. Dotyczy to w szczególności praw rodzicielskich, swobody poruszania się, wolności gospodarczej, sumienia, słowa, nauki i umów

Partia Razem wyraża między innymi poparcie dla ingerencji państwa w pewne kwestie o charakterze socjalnym, natomiast partia Wolność opowiada się za ograniczeniem takich wpływów. $\mathrm{Z}$ badawczego punktu widzenia interesujące może być to, jak będzie wyglądała komunikacja wizualna partii politycznych o znacznie różniących się programach. Określone zostały następujące cele badawcze:

1. Wyodrębnienie typów fotografii pojawiających się w badanym materiale, opisanie ich i określenie częstotliwości ich wykorzystania przez poszczególne partie.

2. Przeprowadzenie analizy porównawczej w celu znalezienia różnic i podobieństw $\mathrm{w}$ wykorzystaniu fotografii przez obie partie.

3. Ustalenie, jakie aspekty związanie z działalnością oraz warstwą ideową partii mogą być zakomunikowane za pomocą fotografii.

Zbudowany został korpus złożony z 253 fotografii i grafik opublikowanych przez wybrane partie w czwartym kwartale 2016 roku$^{5}$. Jako metodę badawczą przyjęto analizę treści, której wykorzystanie w odniesieniu do fotografii opisuje Piotr Sztompka:

W odniesieniu do fotografii analiza treści polega na wyodrębnieniu elementów wizualnych istotnych z punktu widzenia postawionego problemu czy pytania badawczego, obliczeniu częstości ich występowania w starannie dobranej kolekcji zdjęć, a następnie dokonaniu analizy ilościowej rezultatów

Taka analiza powinna pozwolić na odczytanie wielu różnych informacji dotyczących partii politycznych, zwłaszcza takich, które trudno zawrzeć w tekście. Dlatego

1 Nazwa partii została zmieniona w trakcie gromadzenia materiału badawczego.

2 KORWiN: 4,76\%, Razem: 3,62\%.

${ }^{3}$ http://partiarazem.pl/program/ (dostęp: 24 maja 2017).

4 http://wolnosc.pl/program/ (dostęp: 24 maja 2017).

5 Źródła fotografii: https://www.facebook.com/pg/partiarazem/photos/ oraz https://www.facebook. com/pg/jkm.wolnosc/photos/, zakładki „zdjęcia na osi czasu” (dostęp: 26 maja 2018).

6 P. Sztompka, Socjologia wizualna jako metoda badawcza, Warszawa 2005, s. 58. 
też analizowane będą między innymi takie elementy, jak ubiór, płeć fotografowanych osób, miejsce wykonania fotografii oraz obiekty obecne na zdjęciach. Pominięte zaś zostały aspekty związane z kolorystyką, oświetleniem czy też relacją między elementami w kadrze, które byłyby istotne w analizie kompozycyjnej. Skupienie się na nich, a nie na analizie treści, mogłoby spowodować pewne problemy z precyzją badania, na co zwróciła uwagę Gillian Rose:

Podczas gdy interpretacja kompozycyjna pozostaje metodologicznie niema, opierając się na nieostrej i wymykającej się definicjom kategorii „dobrego oka”, analiza treści otwarcie deklaruje swe metodologiczne zasady. U jej podstaw leżą bowiem pewne reguły i procedury, których należy rygorystycznie przestrzegać, aby można było uznać analizę obrazów (czy tekstów) za wiarygodną (w jej kategoriach) ${ }^{7}$.

Warto zauważyć, że na gruncie polskim przeprowadzone już zostało zbliżone tematycznie badanie, opisane przez Kingę Karasek-Kędzior ${ }^{8}$, w którym przeprowadzona została ilościowa (oraz częściowo jakościowa) analiza fotografii publikowanych na portalu Facebook przez partie polityczne. Jednak w przywoływanym opracowaniu główny nacisk położony był na zbadanie samej częstotliwości przesyłania fotografii przez osiem różnych partii i ocenę jej przyrostu po wejściu w okres kampanii wyborczych. Natomiast badanie będące przedmiotem tego artykułu operuje na mniejszym zbiorze danych, złożonym ze zdjęć opublikowanych tylko przez dwie partie, który zostanie za to przeanalizowany w sposób możliwie szczegółowy.

\section{Wyniki badania}

Po utworzeniu korpusu wyodrębniono następujące kategorie materiałów: dokumentacja, portret, grafika, kolaż, screenshot, inne. Następnie została policzona częstość ich wystąpień. Poniżej przedstawiono opisy poszczególnych kategorii:

D oku mentacja - zdjęcia wykonane w trakcie różnych wydarzeń, z perspektywy obserwatora, obecne na nim osoby nie pozują, nie występują też zbliżenia na pojedyncze osoby.

Portret - zdjęcia pojedynczych osób, ukazanych od pasa w górę bądź w jeszcze większym zbliżeniu, z widoczną twarzą. Mogą przedstawiać osoby niepozujące, utrwalone w trakcie różnych działań, podobnie jak często bywa w wypadku portretów prasowych ${ }^{9}$, mogą także przedstawiać osoby pozujące.

Grafika - materiały niezawierające elementów fotograficznych, przedstawiające kompozycje oparte w całości o tekst, symbole, kształty i inne elementy graficzne.

7 G. Rose, Interpretacja materiałów wizualnych. Krytyczna metodologia badań nad wizualnością, Warszawa 2010, s. 83.

8 Zob. K. Karasek-Kędzior, Fotografia polityczna na Facebooku - wykorzystanie grafiki przez partie polityczne, [w:] Technopolityka w świecie nowych mediów, red. M.K. Zwierżdżyński, M. Lakomy, K. Oświecimski, Kraków 2015, s. 261-288.

9 Por. K. Wolny-Zmorzyński, Fotograficzne gatunki dziennikarskie, Warszawa 2007, s. 73. 
Kola ż — zestawienia różnych fotografii bądź ich elementów (na przykład wycięcie osób z kilku zdjęć i przedstawienie ich razem na jednej planszy).

Screenshot - zrzut ekranu komputerowego bądź telewizyjnego, także fotografia ekranu, na którym wyświetlane są różne materiały.

In ne - materiały trudniejsze do jednoznacznego scharakteryzowania, występujące z małą częstotliwością względem pozostałych.

W tabeli 1 zaprezentowane zostały częstości wystąpień materiałów wizualnych poszczególnego rodzaju.

Tabela 1. Rodzaje materiałów wizualnych opublikowanych przez badane partie

\begin{tabular}{|l|r|r|l|r|r|}
\hline \multicolumn{3}{|c|}{ Razem } & \multicolumn{3}{c|}{ Wolność } \\
\hline \multicolumn{1}{|c|}{ Kategoria } & \multicolumn{1}{c|}{$\mathbf{n}$} & \multicolumn{1}{c|}{$\%$} & Kategoria & \multicolumn{1}{c|}{ n } & \multicolumn{1}{c|}{$\%$} \\
\hline dokumentacja & 87 & 63,04 & dokumentacja & 29 & 25,22 \\
\hline portret & 22 & 15,94 & portret & 45 & 39,13 \\
\hline grafika & 13 & 9,42 & grafika & 15 & 13,04 \\
\hline kolaż & 8 & 5,80 & kolaż & 3 & 2,61 \\
\hline inne & 6 & 4,35 & inne & 9 & 7,83 \\
\hline screenshot & 2 & 1,45 & screenshot & 14 & 12,17 \\
\hline suma & 138 & 100,00 & suma & 115 & 100,00 \\
\hline
\end{tabular}

Źródło: opracowanie własne.

Większość $(63,04 \%)$ materiałów opublikowanych przez partię Razem to zdjęcia o charakterze dokumentalnym, druga w kolejności kategoria to portret $(15,94 \%)$. Natomiast w materiałach partii Wolność pierwsze miejsce zajmuje kategoria zdjęć portretowych $(39,13 \%)$, a drugie dokumentalnych (25,22\%). Grafiki niezawierające elementów fotograficznych stanowiły tylko 9,42\% publikacji partii Razem i 13,04\% materiałów partii Wolność.
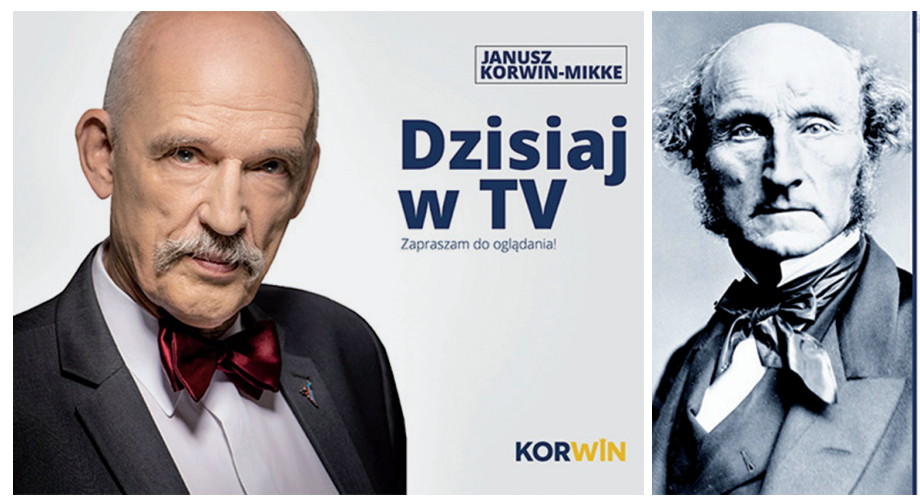

\section{JOHN STUART MILL}

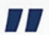

Ludzkość zyskuje więcej, pozwalając żyć każdemu wedle jego upodobania, niż zmuszając każdego, by żył wedle upodobania pozostałych.

\#wolność

Ilustracja 1. Materiały fotograficzne partii Wolność/KORWiN — przykłady kategorii „portret”

Źródło: Oficjalny profil partii Wolność/KORWiN, https://www.facebook.com/pg/jkm.wolnosc/photos/ (dostęp: 26 maja 2018).

Dziennikarstwo i Media 9, 2018

(C) for this edition by CNS 


\section{Fotografie portretowe}

Jako pierwsze przeanalizowane zostały fotografie portretowe. Wymiary analizy razem $\mathrm{z}$ odpowiadającymi im kategoriami zostały przedstawione w tabeli 2.

Tabela 2. Fotografie portretowe - wymiary analizy

\begin{tabular}{|l|l|}
\hline Badany wymiar & \multicolumn{1}{c|}{ Kategorie } \\
\hline osoba & politycy partii, przeciwnicy polityczni, autorytety, prezes partii \\
\hline ubiór & formalny, półformalny, nieformalny \\
\hline pozowanie & osoba pozuje, osoba nie pozuje \\
\hline płeć & mężczyzna, kobieta \\
\hline
\end{tabular}

Źródło: opracowanie własne.

Wymiar „osoba” służy określeniu tego, kto jest widoczny na badanym zdjęciu. Może być to polityk danej partii (lub, w szczególnym wypadku, jej prezes), przeciwnik polityczny (osoba przedstawiona w negatywnym kontekście, nienależąca do danej partii) bądź autorytet. Za autorytety, zgodnie z rozumieniem Michaela Fleischera, zostały uznane takie osoby, „które w danym dyskursie posiadają moc (lub taka moc może być dla nich postulowana albo założona) komunikacyjnie lub społecznie relewantnej instancji” 10 - czyli, przykładowo, postaci historyczne pojawiające się w pozytywnym kontekście, ekonomiści, naukowcy i podobne osoby, niebędące politykami danej partii.

U bió r został przeanalizowany w taki sposób, aby możliwa była ocena stopnia „sformalizowania” prezentowanych osób. Za przykłady strojów nieformalnych uznane zostały bluzy, swetry, koszulki i podobne ubrania, za półformalne: koszule, marynarki bez krawatów, niektóre rodzaje sukienek, stroje formalne zaś to przede wszystkim garnitury i garsonki.

Po z o w a n i e — kodowane było to, czy poszczególne osoby pozują lub przybierają wskazującą na taki fakt posturę.

Płe ć - określono liczbę kobiet i liczbę mężczyzn obecnych na fotografiach portretowych, aby sprawdzić, czy występują tendencje do częstszego przedstawiania osób wybranej płci.

Każdą fotografię przypisano do jednej kategorii z każdego wymiaru, następnie obliczono częstotliwość ich występowania i dokonano analizy porównawczej.

10 M. Fleischer, Ogólna teoria komunikacji, Wrocław 2007, s. 175. 
Tabela 3. Porównanie osób na fotografiach portretowych obu partii

\begin{tabular}{|l|r|r|l|r|c|}
\hline \multicolumn{3}{|c|}{ Razem } & \multicolumn{3}{c|}{ Wolność } \\
\hline \multicolumn{1}{|c|}{ Osoby } & \multicolumn{1}{c|}{$\mathbf{n}$} & \multicolumn{1}{c|}{$\%$} & \multicolumn{1}{c|}{ Osoby } & $\mathbf{n}$ & \multicolumn{1}{c|}{} \\
\hline prezes partii & 0 & 0,00 & prezes partii & $\mathbf{1 5}$ & $\mathbf{3 3 , 3 3}$ \\
\hline autorytet & 5 & 22,73 & autorytet & $\mathbf{1 4}$ & $\mathbf{3 1 , 1 1}$ \\
\hline politycy partii & 8 & 36,36 & politycy partii & 11 & 24,44 \\
\hline przeciwnicy & $\mathbf{9}$ & $\mathbf{4 0 , 9 1}$ & przeciwnicy & 5 & 11,11 \\
\hline suma & 22 & 100,00 & suma & 45 & 100,00 \\
\hline
\end{tabular}

Źródło: opracowanie własne.

Partia Wolność najczęściej pokazuje swojego prezesa (33,33\%), natomiast partia Razem prezesa, czy też lidera, nie ma w ogóle ${ }^{11}$, choć za takiego w mediach uznawany bywał Adrian Zandberg ${ }^{12}$. Na portrecie został on przedstawiony tylko jeden raz ${ }^{13}$, więc nie jest osobą szczególnie promowaną z użyciem fotografii. Gdyby kategorię „prezes partii” połączyć z kategorią „politycy partii”, partia Wolność uzyskałaby wynik 57,77\%, który byłby zauważalnie wyższy niż w wypadku partii Razem $(36,36 \%)$. Największy kontrast występuje w kategorii przeciwników politycznych: 40,91\% w wypadku partii Razem i 11,11\% w wypadku partii Wolność.

Najbardziej charakterystyczną różnicą jest płeć pokazywanych osób (tabela 4). W materiałach partii Razem występuje niewielka przewaga kobiet, druga partia pokazuje zaś niemal wyłącznie mężczyzn (93,33\%).

Tabela 4. Porównanie płci osób na fotografiach portretowych obu partii

\begin{tabular}{|l|c|c|l|c|c|}
\hline \multicolumn{3}{|c|}{ Razem } & \multicolumn{3}{c|}{ Wolność } \\
\hline \multicolumn{1}{|c|}{ Płeć } & n & \% & Płeć & n & \% \\
\hline mężczyzna & 9 & 40,91 & mężczyzna & $\mathbf{4 2}$ & $\mathbf{9 3 , 3 3}$ \\
\hline kobieta & $\mathbf{1 3}$ & $\mathbf{5 9 , 0 9}$ & kobieta & 3 & 6,67 \\
\hline suma & 22 & 100,00 & suma & 45 & 100,00 \\
\hline
\end{tabular}

Źródło: opracowanie własne.

Interesujące jest również porównanie strojów występujących na badanych fotografiach. Partia Razem pokazuje najwięcej nieformalnych, a w wypadku partii Wolność dominują garnitury i inne formalne stroje $(84,44 \%)$, rzadziej białe koszule lub marynarki bez krawatów. Stroje całkowicie nieformalne w tej partii nie występują.

11 http://partiarazem.pl/program/ (dostęp: 2 lutego 2017).

12 T. Goban-Klas, Efekt Zandberga jako splot wizerunkowego wplywu starych i nowych mediów, [w:] Technopolityka w świecie nowych mediów..., s. 29.

13 Fotografia z 16 października 2016 roku. Źródło: https://www.facebook.com/partiarazem/photos/a.430709850430410/674633692704690/ (dostęp: 22 stycznia 2017). 
Tabela 5. Porównanie ubioru fotografowanych osób

\begin{tabular}{|l|c|c|l|r|r|}
\hline \multicolumn{3}{|c|}{ Razem } & \multicolumn{3}{c|}{ Wolność } \\
\hline \multicolumn{1}{|c|}{ Strój } & $\mathbf{n}$ & $\mathbf{\%}$ & \multicolumn{1}{c|}{ Strój } & n & \% \\
\hline formalny & 7 & 31,82 & formalny & $\mathbf{3 8}$ & $\mathbf{8 4 , 4 4}$ \\
\hline półformalny & 6 & 27,27 & półformalny & 7 & 15,56 \\
\hline nieformalny & $\mathbf{9}$ & $\mathbf{4 0 , 9 1}$ & nieformalny & 0 & 0,00 \\
\hline suma & 22 & 100,00 & suma & 45 & 100,00 \\
\hline
\end{tabular}

Źródło: opracowanie własne.

Można odnieść wrażenie, że partia Wolność posiada pewne standardy dotyczące wyglądu swoich polityków - są to głównie formalnie ubrani mężczyźni i rzadko pojawiają się odstępstwa od tej reguły. W wypadku partii Razem stroje nie są ujednolicone, choć widoczna jest tendencja do unikania ubioru formalnego.

Tabela 6. Zdjęcia pozowane i niepozowane

\begin{tabular}{|l|c|c|l|c|c|}
\hline \multicolumn{3}{|c|}{ Razem } & \multicolumn{3}{c|}{ Wolność } \\
\hline Pozowane & n & \% & Pozowane & n & $\%$ \\
\hline tak & 8 & 36,36 & tak & $\mathbf{3 4}$ & $\mathbf{7 5 , 5 6}$ \\
\hline nie & $\mathbf{1 4}$ & $\mathbf{6 3 , 6 4}$ & nie & 11 & 24,44 \\
\hline suma & 22 & 100,00 & suma & 45 & 100,00 \\
\hline
\end{tabular}

Źródło: opracowanie własne.

Większość fotografii portretowych $(63,64 \%)$ w wypadku partii Razem nie była pozowana - oznacza to, że zdjęcia co prawda miały charakter portretowy, czyli skupiały się w całości na pokazaniu jednej osoby, jednak były wykonywane spontanicznie, przedstawiając fotografowaną osobę w trakcie jakiegoś działania, na przykład przemawiającą w miejscu publicznym. Natomiast w wypadku partii Wolność większość fotografii sprawia wrażenie pozowanych $(75,56 \%)$, często wykonywanych $\mathrm{w}$ warunkach studyjnych.

\section{Fotografie dokumentalne}

Kolejnym etapem badania było przeprowadzenie analizy fotografii dokumentalnych. Tego typu zdjęcia dokumentują między innymi przedstawicieli partii pojawiających się w miejscach publicznych, pokazują też różnego rodzaju wydarzenia o charakterze politycznym. W przeciwieństwie do analizowanych wcześniej fotografii portretowych nie są tutaj prezentowane pojedyncze osoby, lecz bardziej złożone sceny. Występuje także więcej elementów możliwych do opisania - na części fotografii obecne są 
flagi, transparenty i inne obiekty, których rodzaj i częstotliwość pojawiania się może dostarczyć istotnych informacji dotyczących charakterystyki danej partii.

Zakodowane zostały kategorie wydarzeń, osób oraz obiektów widocznych na poszczególnych fotografiach. Tabela 7 zawiera spis wszystkich kategorii.

Tabela 7. Badane wymiary i kategorie elementów obecnych na fotografiach dokumentalnych

\begin{tabular}{|l|l|}
\hline Badany wymiar & \multicolumn{1}{|c|}{ Kategorie } \\
\hline wydarzenie & $\begin{array}{l}\text { manifestacja, manifestacja zagraniczna, manifestacja przeciwników, spotkanie } \\
\text { z partią, wydarzenie polityczne, wydarzenie historyczne, wywiad, wojna, czas } \\
\text { wolny, inne }\end{array}$ \\
\hline miejsce & wnętrze budynku, ulica/plener \\
\hline osoby & $\begin{array}{l}\text { tłum, politycy partii, dziennikarze, aktywiści, widownia, ofiary } \\
\text { prezes partii, inne }\end{array}$ \\
\hline obiekty & transparenty, flaga Polski, flaga UE, logo partii, broń, gra planszowa, budzik ${ }^{13}$ \\
\hline
\end{tabular}

Źródło: opracowanie własne.

Kategorie w y d a r z eń zostały opracowane w taki sposób, aby opisywały w sposób ogólny tematykę badanych fotografii. Przykładowo: tłum ludzi niosących transparenty $\mathrm{z}$ hasłami został określony jako ma n ife stacja. Do każdej fotografii został przypisany tylko jeden rodzaj wydarzenia.

Miejsce zostało określone jako wnętrze budynku lub ulica/plener i dostarcza ogólnej informacji na temat tego, w jakiej przestrzeni dana fotografia została wykonana.

Kategorie o s ób występujących na zdjęciach zostały utworzone w taki sposób, aby rozróżnić sytuacje, w których ludzie są pokazywani jako część większego zgromadzenia (kategorie takie, jak tł u m, wi d ow n i a), oraz takie, w których pewne osoby i grupy osób są mocniej wyeksponowane (przykładowo: prezes lub d zien nika r z e). Jedna fotografia może przedstawiać osoby z kilku kategorii.

Zostały także wyodrębnione kategorie dla najbardziej charakterystycznych obiektów obecnych na zdjęciach. Odnotowane były głównie wystąpienia takich elementów, które osoby obecne na zdjęciach wnosiły, w sensie dosłownym, w przestrzeń publiczną - na przykład transparenty i flagi. Kodowany był fakt obecności jakiegoś obiektu na zdjęciu i nie było liczone, ile razy on występuje na tej samej fotografii, nie zostały też zanotowane wystąpienia wszystkich widocznych obiektów (na przykład elementów krajobrazu, ubioru).

Podobnie jak w wypadku portretów, występują różnice w zawartości zdjęć dokumentalnych publikowanych przez obie partie. Ukazane zostały one w tabeli 8 .

14 Przedstawienie ofiar wojennych, osób poszkodowanych w różnych sytuacjach.

15 Obiekt związany z tematyką manifestacji partii KORWiN (Obudź się Europo). 
Tabela 8. Porównanie kategorii wydarzeń widocznych na fotografiach dokumentalnych obu partii

\begin{tabular}{|l|r|r|l|r|r|}
\hline \multicolumn{4}{|c|}{ Razem } & \multicolumn{3}{c|}{ Wolność } \\
\hline \multicolumn{1}{|c|}{ Wydarzenie } & $\mathbf{n}$ & \multicolumn{1}{c|}{$\%$} & Wydarzenie & $\mathbf{n}$ & \multicolumn{1}{c|}{$\%$} \\
\hline manifestacja & $\mathbf{5 8}$ & $\mathbf{6 6 , 6 7}$ & spotkanie & $\mathbf{1 5}$ & $\mathbf{5 1 , 7 2}$ \\
\hline wywiad & 12 & 13,79 & manifestacja & 10 & 34,48 \\
\hline historyczne & 5 & 5,75 & czas wolny & 2 & 6,90 \\
\hline $\begin{array}{l}\text { manifestacja } \\
\text { zagraniczna }\end{array}$ & 4 & 4,60 & polityczne & 1 & 3,45 \\
\hline polityczne & 2 & 2,30 & historyczne & 1 & 3,45 \\
\hline wojna & 2 & 2,30 & suma & 29 & 100,00 \\
\hline $\begin{array}{l}\text { manifestacja } \\
\text { przeciwników }\end{array}$ & 1 & 1,15 & & & \\
\hline inne & 3 & 3,45 & & & \\
\hline suma & 87 & 100,00 & & & \\
\hline
\end{tabular}

Źródło: opracowanie własne.

Dominującą kategorią wydarzenia w wypadku partii Wolność było „spotkanie” (51,72\%), w materiałach partii Razem zaś taka kategoria nie wystąpiła w ogóle. W tę kategorię wpisane zostały sytuacje, w której wyborcy (lub inne zainteresowane osoby) spotykają się z przedstawicielami partii w zamkniętej przestrzeni, przyjmując głównie rolę słuchaczy. Partia Razem najczęściej pokazywała manifestacje $(66,67 \%)$, które w wypadku drugiej partii także wystąpiły, lecz rzadziej (34,48\%). Uliczne manifestacje także pozwalają na kontakt $z$ wyborcami, choć odbywający się na innych regułach niż podczas zamkniętych spotkań.

Istotne różnice pojawiły się także po porównaniu miejsc wykonania badanych fotografii. Wyniki zostały przedstawione w tabeli 9.

Tabela 9. Porównanie kategorii miejsc widocznych na fotografiach dokumentalnych obu partii

\begin{tabular}{|l|r|r|l|c|c|}
\hline \multicolumn{3}{|c|}{ Razem } & \multicolumn{3}{c|}{ Wolność } \\
\hline \multicolumn{1}{|c|}{ Miejsce } & \multicolumn{1}{c|}{$\mathbf{n}$} & \multicolumn{1}{c|}{$\%$} & \multicolumn{1}{c|}{ Miejsce } & n & \multicolumn{1}{c|}{$\%$} \\
\hline ulica/plener & $\mathbf{8 4}$ & $\mathbf{9 6 , 5 5}$ & ulica/plener & 12 & 41,37 \\
\hline wnętrze budynku & 3 & 3,45 & wnętrze budynku & $\mathbf{1 7}$ & $\mathbf{5 8 , 6 2}$ \\
\hline suma & 87 & 100,00 & suma & 29 & 100,00 \\
\hline
\end{tabular}

Źródło: opracowanie własne.

Niemal wszystkie fotografie partii Razem zostały wykonane na ulicy lub w innych sytuacjach plenerowych (96,55\%), a większość zdjęć drugiej partii dokumentowało wydarzenia dziejące się we wnętrzach budynków $(58,62 \%)$.

W kolejnej tabeli porównane są kategorie osób występujących na zdjęciach. Pojawiły się różnice w liczbie i nazewnictwie kategorii. Każda fotografia mogła jednocześnie 
przedstawiać różne osoby, dlatego tabele uwzględniają procent wystąpień danej kategorii w stosunku do sumy wszystkich wystąpień oraz w stosunku do liczby fotografii.

Tabela 10. Porównanie kategorii osób widocznych na fotografiach dokumentalnych obu partii

\begin{tabular}{|l|r|r|r|r|r|r|c|}
\hline \multicolumn{5}{|c|}{ Razem } & \multicolumn{4}{c|}{ Wolność } \\
\hline Osoby & $\mathbf{n}$ & $\begin{array}{c}\text { \% } \\
\text { wystąpień }\end{array}$ & $\begin{array}{c}\text { \% } \\
\text { fotografii }\end{array}$ & Osoby & $\mathbf{n}$ & $\begin{array}{c}\text { \% } \\
\text { wystąpień }\end{array}$ & $\begin{array}{c}\text { \% } \\
\text { fotografii }\end{array}$ \\
\hline politycy partii & 25 & 24,51 & 28,73 & widownia & 11 & 26,83 & 37,93 \\
\hline dziennikarze & 12 & 11,76 & 13,79 & tłum & 10 & 24,39 & 34,48 \\
\hline aktywiści & 4 & 3,92 & 4,59 & prezes partii & 8 & 19,51 & 27,58 \\
\hline $\begin{array}{l}\text { tłum - } \\
\text { zbliżenie }\end{array}$ & 3 & 2,94 & 3,44 & inni politycy & 1 & 2,44 & 3,44 \\
\hline ofiary & 3 & 2,94 & 3,44 & suma & 41 & 100,00 & 144,81 \\
\hline inni & 1 & 0,98 & 1,14 & & & & \\
\hline suma & 102 & 100,00 & 117,19 & & & & \\
\hline
\end{tabular}

Źródło: opracowanie własne.

W wypadku partii Razem na większości zdjęć obecny był tłum (62,06\%), natomiast na fotografiach partii Wolność najczęściej pojawiali się politycy partii $(41,38 \%)-$ gdyby dodać wynik z kategorii „prezes partii”, okazałoby się, że aż 68,96\% zdjęć przedstawiało wyróżniających się polityków. Na zdjęciach partii Wolność pojawiała się także kategoria „widownia” (obecna na spotkaniach partyjnych), która nie była widoczna w wypadku partii Razem.

Tabela 11. Porównanie kategorii obiektów widocznych na fotografiach dokumentalnych obu partii

\begin{tabular}{|l|r|r|l|r|c|}
\hline \multicolumn{3}{|c|}{ Razem } & \multicolumn{4}{c|}{ Wolność } \\
\hline \multicolumn{1}{|c|}{ Obiekty } & \multicolumn{1}{c|}{$\mathbf{n}$} & \% wystąpień & \multicolumn{1}{c|}{ Obiekty } & \multicolumn{1}{c|}{$\mathbf{n}$} & \% wystąpień \\
\hline transparenty & $\mathbf{5 3}$ & $\mathbf{6 3 , 8 6}$ & transparenty & $\mathbf{8}$ & $\mathbf{3 8 , 1 0}$ \\
\hline logo partii & 18 & 21,69 & flaga polski & $\mathbf{8}$ & $\mathbf{3 8 , 1 0}$ \\
\hline flaga polski & 5 & 6,02 & logo partii & 2 & 9,52 \\
\hline tęczowa flaga & 5 & 6,02 & broń & 1 & 4,76 \\
\hline flaga ue & 2 & 2,41 & gra planszowa & 1 & 4,76 \\
\hline suma & 83 & 100,00 & budzik & 1 & 4,76 \\
\hline & & & suma & 21 & 100,00 \\
\hline
\end{tabular}

Źródło: opracowanie własne.

Dziennikarstwo i Media 9, 2018

(C) for this edition by CNS 
$\mathrm{Na}$ fotografiach dokumentalnych partii Razem licznie pojawiały się transparenty (63,86\% wystąpień). Były one obecne, z mniejszą częstotliwością, także w wypadku drugiej partii $(38,10 \%)$. Partia Wolność równie często jak transparenty pokazywała flagę Polski $(38,10 \%)$, która w wypadku partii Razem pojawiała się zdecydowanie rzadziej (6,02\% wystąpień). Partia Razem pokazywała także tęczowe flagi $(6,02 \%)$, które mogą być kojarzone z ruchami LGBT i pokrewnymi. W wypadku drugiego ugrupowania nie występowały one w ogóle.

\section{Podsumowanie}

Przegląd fotografii publikowanych przez partie polityczne może dostarczyć wielu informacji na ich temat, zwłaszcza w momencie, gdy możliwe jest porównanie materiałów różnych partii. Już wstępna analiza pozwoliła na dostrzeżenie pewnych różnic - partia Razem publikowała głównie fotografie dokumentalne, natomiast Wolność portretowe. Na fotografiach dokumentalnych pokazywane były głównie bieżące działania, portrety pozwalały zaś na prezentowanie i promowanie poszczególnych polityków i innych osobistości bądź wskazywanie przeciwników politycznych. Analiza wykazała, że badane partie miały nieco odmienne priorytety. Na personalny aspekt położyła nacisk partia Wolność, publikując wiele portretów, w szczególności pokazujących prezesa, natomiast partia Razem przedstawiła wiele zdjęć dokumentujących wydarzenia, takie jak manifestacje uliczne. Istotną obserwacją było też to, że partia Wolność na portretach w ogóle nie przedstawiała nieformalnie ubranych osób, a w wypadku partii Razem występowała większa dowolność ubioru. Największą różnicę udało się dostrzec po obliczeniu częstości pojawiania się kobiet i mężczyzn na portretach - partia Wolność pokazywała niemal wyłącznie mężczyzn, natomiast nieco ponad połowa portretów partii Razem przedstawiała kobiety. Tego typu analiza może służyć sprawdzeniu tego, czy w danej partii są realizowane postulaty związane z parytetami płci, feminizmem, maskulinizmem bądź innymi ideami. Różnego rodzaju idee mogą przejawiać się także w symbolice widocznej na zdjęciach. $\mathrm{Na}$ fotografiach partii Razem obecne były tęczowe flagi, co prawda z niezbyt wielką częstotliwością, ale w wypadku partii Wolność nie pojawiły się one w ogóle. Podczas prowadzenia analizy porównawczej istotne jest więc odnotowywanie także takich elementów, które się w danym miejscu nie pojawiają.

Warto zauważyć, że dopiero całościowe spojrzenie na publikowane fotografie pozwala wyciągnąć opisywane wnioski - przy przeglądaniu albumów złożonych z wielu zdjęć dobrze widoczne są powtarzające się elementy, które mogłyby pozostać niezauważone podczas oglądania pojedynczych fotografii. Mimo że w badanym okresie nie zbliżały się wybory, publikowano wiele zdjęć pokazujących polityków i bieżącą aktywność partii. Publikowanie fotografii w portalach społecznościowych przez partie 
polityczne może być więc postrzegane jako działanie będące elementem tak zwanej kampanii permanentnej ${ }^{16}$. Przeglądanie takich materiałów pozwala na sprawdzenie, którzy politycy są aktualnie najchętniej prezentowani, w jakich miejscach są oni obecni i jaka problematyka jest podejmowana przez partie. Analiza fotografii może więc stanowić dobre narzędzie do śledzenia bieżącej komunikacji partii politycznych oraz porównywania tego, co dane partie pokazują na zdjęciach, z tym, co deklarują w swoich tekstach czy wypowiedziach polityków.

\section{Study of political parties' communication based on photographs published online}

\section{Summary}

This article contains a description of an empirical study the aim of which was to analyze the photographs published online by two Polish political parties: Razem and Wolność (KORWiN). A corpus containing 253 images and photos published by the two parties in the forth quarter of 2016 was constructed and a quantitative analysis was performed afterwards. Documentary and portrait photos, which appeared most frequently in the corpora were carefully analyzed on the basis of such factors as: the frequency at which particular persons appeared in the photos, the clothes they were wearing, the type of events depicted in the pictures and the kinds of objects which were shown most often.

16 J. Garlicki, Komunikowanie polityczne - od kampanii wyborczych do kampanii permanentnej, „Studia Politologiczne” 16, 2010, s. 26-45.

Dziennikarstwo i Media 9, 2018

(C) for this edition by CNS 